\title{
An Informed Public, an Informing Press: The Search for a Constitutional Principle
}

\author{
Lillian R. BeVier†
}

Rhetoric suggesting that there is a "right of the people . . . to govern im an informed manner," and that the press has a "constitutionally designated function in informing the public" 2 frequently embellishes first amendinent opinions. On the surface such rhetorical statements do not strike a discordant note. They seem hardly novel propositions, and thus do not cry out for critical analysis. We do, after all, live in a democracy, and it is part of our tradition to think of ourselves as taking seriously our obligations as citizens. It is a truism that we cannot responsibly exercise our franchise unless we have sufficient knowledge about governmental affairs, operations, and policies to make informed choices among candidates. We therefore feel in some sense entitled to a certaim amount of information about what government is doimg; thus we are often outraged when we learn of government attempts to practice secrecy upon us. And it is surely a fact that the press has played a crucial, indeed indispensible, role throughout our history in informing us about our government's deeds and misdeeds.

In recent years, however, two developments have occurred which put to the test the constitutional substance of familiar rhetorical affirmations of our "rights" to govern in an informed manner and of the press" "constitutionally designated" function of informing us. The first of these developments is the appearance im the legal literature of arguments by prominent and respected commentators about whether the "press clause" of the first amendment ought to be construed imdependently of the "speech clause" so that new constitutional doctrime can be developed (or existing doctrime remterpreted) to give explicit

$\dagger$ Professor of Law, University of Virginia School of Law. B.A. 1961, Smith College; J.D. 1965, Stanford University.

I am indebted to nyy colleagues John Jeffries and Paul Stephan for their insightful comments on an earher draft. The errors that remain are my own.

I am also grateful to Michael Clayton, a third-year law student, who provided useful research assistance.

1. Pell v. Procunier, 417 U.S. 817, $839-40$ (1974) (Douglas, J., dissenting).

2. Zurcher v. Stanford Daily, 436 U.S. 547, 572 (1972) (Stewart, J., dissenting). See also, e.g., Mills v. Alabama, 384 U.S. 214, 218 (1966). 
protection to the press' informing function. ${ }^{3}$

The second development is the appearance of Supreme Court cases in which the press has invited the Court affirmatively to guarantee, by means of constitutional rules specifically formulated to vindicate, the values of an informed public and an informing press. In particular, the "press privilege" cases ${ }^{4}$ have invited the Court to include prepublication activities such as the gathering of news ${ }^{5}$ within the constitutional shield which has traditionally insulated the act of publication from affirmative governmental interference, the theory being that expanded protection is necessary to insure the flow of information to the public. And the prison ${ }^{6}$ and courtroom ${ }^{7}$ access cases have sought to turn the first ainendment into a sword by imposing an affirmative obligation on government to open its activities to public scrutiny as a means of securing a public right to govern in an informed manner.

These twin developments raise a fundainental question: Does the first amendment in general, or the press clause in particular, vindicate in principle the public's right to be informed? This question is ultimately unavoidable because both the assertion that the Constitution provides protection to the press as an institution and the privilege and access claims are grounded on the imphicit premise that the Constitution assigns affirmative value to an informed public. Without such a premise, the concept of the press as an institution with a "constitutionally established role" 8 of providing "organized, expert scrutimy of government"" is an empty if not an invidious one. In the privilege cases,

3. See, e.g., Lange, The Speech and Press Clause, 23 U.C.L.A. L. REv. 77 (1975); Nimmer, Introduction-Is Freedom of the Press a Redundancy: What Does It Add to Freedom of Speech?, 26 Hastings L.J. 639 (1975); Stewart, "Or of the Press," 26 HaStings L.J. 631 (1975).

4. Herbert v. Lando, 441 U.S. 153 (1979); Zurcher v. Stanford Daily, 436 U.S. 547 (1978); Branzburg v. Hayes, 408 U.S. 665 (1972).

5. Publication itself has long been the subject of explicit constitutional protection. The right to publish is protected, for example, from prior restraimt, see, e.g., Near v. Minnesota, 283 U.S. 697 (1931), and from subsequent punishment, see, e.g., Landmark Communications, Inc. v. Virginia, 435 U.S. 829 (1978). The Court has also protected the right of a recipient to receive already published matter. See Lamont v. Postmaster Gen., 381 U.S. 301 (1965). Beginning with Branzburg v. Hayes, 408 U.S. 665 (1972), the Court has heard arguments stressing the critical importance of newsgathering as a step in the process of publication and considered claims that newsgathering ought to be given exphicit protection. The concept and some of the potential doctrinal consequences of a right to gather news have been abundantly explored in the law reviews. See, e.g., Note, The Right of the Press to Gather Information, 71 ColuM. L. Rev. 838 (1971); Comment, The Right of the Press to Gather Information After Branzburg and Pell, 124 U. PA. L. REv. 166 (1975); Note, Reporters and Their Sources: The Constitutional Right to a Confidential Relationship, 80 YALE L.J. 317 (1970).

6. Houchims v. KQED, Inc., 438 U.S. 1 (1978); Saxbe v. Washington Post Co., 417 U.S. 834 (1974); Pell v. Procunier, 417 U.S. 817 (1974).

7. Gannett Co. v. DePasquale, 99 S. Ct. 2898 (1979).

8. Saxbe v. Washington Post Co., 417 U.S. 843, 864 (1974) (Powell, J., dissenting).

9. Stewart, supra note 3 , at 634 . 
the premise is essential to the argument that governmental regulations which have the predictable effect of imterfering with the flow of information to the public (but which are not claimed to interfere with the freedom to publish) are constitutionally suspect. And in the access cases, the premise is essential to the argument that the public enjoys a constitutional "right to know"10 inforination within the government's control.

The principal purpose of this Article is to address the fundamental question whether the first amendment ought to be conceivcd of as a guarantee that the public be well informed. The analysis will approach the question by focusing on what is clearly the most far-reaching implication of such a conception, namely the implication that the public has a constitutional right to infornation within the government's control. The Article is skeptical about whether the Court's rhetorical affinnations of the public's right to be informed and the press' contribution to the flow of information, which have served so well to justify rules which protect publication from governmental prohibition or restraint, can legitimately be invoked to transform the Constitution into a vehicle for imposing a duty to disclose upon the government. ${ }^{11}$

Part I of the Article briefly discusses several recent press cases. The purpose is to place the common premises of the claims made in the prison and courtroom access cases and the press privilege cases in an appropriate doctrinal context. To this end, the issues those cases presented are contrastcd to issues raised by recent press cases which fit more precisely within traditional first amendment doctrinal patterus. The analytical burden of Part $I$ is to demonstrate that neither traditional doctrimal fornulations nor the Court's decisions in the access and privilege cases support the view that the values of a well-informed

10. In this Article, the term "right to know" denotes a personal right held by every member of the public to lave access to information controlled by the government. The term is thus used throughout thc Article in a technical legal sense and, as an aid to analytical clarity, it extends by definition "as far as dry logic might extend." Saxbe v. Washnigton Post Co., 417 U.S. 843, 860 (1974) (Powell, J., dissenting). It includes, therefore, the assumption that it is a right possessed by individuals, who would have standing to sue whenever government denied them access to information. The correlative of the right is the affirmative governmental duty to disclose mformation. This use of the term is premised on the belief that it is misleading to invoke a right to know im constitutional discourse without being at least aware of the inherent legal logic of the term. For a description of other meanings which have been attributed to the "public right to know," see Emerson, Legal Foundations of the Right to Know, 1976 WASH. U.L.Q. 1, 5-20; Note, Public and Press Rights of Access to Prisoners Afler Branzburg and Mandel, 82 YALE L.J. 1337, 1343-45 (1973).

11. Although it would be inaccurate to suggest that other commentators have reached an articulate consensus on the point, most seem persuaded that the rhetoric in fact at least describes interests which are worthy of constitutional protection. From the premise that the rhetoric contains more than a grain of theoretical truth, they reason to a variety of doctrinal conclusions. See, e.g., Bezanson, The New Free Press Guarantee, 63 VA. L. Rev. 731 (1977); Blasi, The Checking Value in First Amendment Theory, 1977 AM. BAR FOUND. RESEARCH J. 521; Lange, supra note 3; Nimmer, supra note 3; Stewart, supra note 3. 
public and of the press' role in providing information liave been accorded independent constitutional significance by the Court.

Part II of the Article addresses the specific question of whether the public ought to have a constitutional right to know governmental information. Approaching the question from a theoretical perspective, it offers general criteria for judging the legitimacy of constitutional principles and evaluates the claim for a public right to know in terms of the offered criteria. Part II attempts to ascertain what can be inferred about the right to know from the processes of representative government prescribed by the Constitution. A broad consensus currently exists that there is a crucial connection between constitutionally prescribed democratic processes and the press clause. ${ }^{12}$ This consensus has induced an almost casual acceptance of facile generalizations about the right of the public to govern in an inforned inanner and about the press' function in disseminating relevant infornation. But the precise theoretical content, not to incntion the doctrinal import, of the connection between press freedoin and the democratic pohtical process remains surprisingly obscure. To examine this connection, Part II considers the nature of democratic government as it is structured by the Constitution and critically examines its relationship to press freedom. The Article concludes that a right to know cannot be sustained as a matter of constitutional primciple.

\section{First Amendment Doctrine AND the Right to KNow}

\section{A. The Traditional Press Freedom Cases}

Litigation concerning the meaning of freedom of the press lias traditionally focused on the validity of governmental regulation that intcrferes with the freedoin to publish. ${ }^{13}$ The first amendment doctrine that einerges from the cases rests on a broad consensus that political speech $^{14}$ is at the core of the amendment's concern. Accordingly, the Court lias held that the amendinent clearly protects cominunications

12. $C$. Mills v. Alabama, 384 U.S. 214, 218 (1966) (referring to "practically universal agreement that a major purpose of [the First] Amendment was to protect the free discussion of government affairs").

13. Regulations interfering with the freedom of activities ancillary to publication have also been litigated. See, e.g., Lamont v. Postmaster Gen., 381 U.S. 301 (1965) (freedom to receive published material); Lovell v. Griffin, 303 U.S. 444 (1938) (freedom to distribute publications).

14. Pohitical speech has been variously defined as "speech concerned with governmental behavior, policy or personnel, whether the governmental unit involved is executive, legislative, judicial or administrative; . . . speech about how we are governed . . . [including] a wide range of evaluation, criticism, electioneering and propaganda," Bork, Neutral Principles and Some First Amendment Problems, 47 IND. L.J. 1, 27-28 (1971); and as speech which participates in "the process of forming and expressing the will of the majority according to whicli our representatives must 
about governmental activities and debate about political affairs, and has developed doctrines to insulate publications containing politically relevant information from most instances of affirmative governmental sanction, whether im the form of prior restraint, ${ }^{15}$ criminal punishment, ${ }^{16}$ or civil damages. ${ }^{17}$ In recent years the Supreme Court has decided several cases in which the press challenged regulation whicl, if sustamed, would liave threatened the area of press freedom that previous decisions had established. The Court in these cases fully respected, and even expanded, prior doctrinal boundaries. ${ }^{18}$

These traditional cases presented classic first amendment issues. The challenged regulations fell directly upon particular published material $^{19}$ and were triggered by the content of the publication. The first amendment was invoked as a shield to protect publication froin direct governmental sanction, and in its literal and formal sense freedom of the press was thereby vindicated. Yet in these cases the Court did not justify its decisions simply by endorsing the value of freedom as a constitutional end. To the contrary, the opinions intinuated that freedom was merely a ineans of securing "interests in public scrutmy and discussion of governmental affairs which the first amendment was adopted to protect," 20 and hinted at the relevance to the decisions of the view that "[w]ithout the inforination provided by the press niost of us . . . would be unable to vote intelligently or to register opinions on the administration of government generally."21 These statements appear to suggest that the interests in public scrutiny and discussion of governmental affairs and the role of the press in providing relevant political informa-

govern." BeVier, The First Amendment and Political Speech: An Inquiry Into the Substance and Limits of Principle, 30 STAN. L. REv. 299, 309 (1978).

15. See, e.g., New York Times Co. v. United States, 403 U.S. 713 (1971).

16. See, e.g., Brandenburg v. Ohio, 395 U.S. 444 (1969).

17. See, e.g., New York Times Co. v. Sullivan, 376 U.S. 254 (1964).

18. See Smith v. Daily Mail Publishing Co., 99 S. Ct. 2667 (1979) and Landmark Communications, Inc. v. Virginia, 435 U.S. 829 (1978) (both imvalidating statutes that provided criminal punishment for publication of truthful information); Nebraska Press v. Stewart, 427 U.S. 539 (1976), and New York Times Co. v. United States, 403 U.S. 713 (1971) (both reaffinning the doctrine that regulations taking the form of "prior restraints" of speech or publication bear an unusually heavy burdeu of justification); Cox Broadcasting v. Cohen, 420 U.S. 469 (1975) (invalidating a state's civil damage reinedy for the publication of truthful information contained in public records); Gertz v. Robert Welch Inc., 418 U.S. 323 (1974) (holding that states are not free to impose hability without fault for defamatory speech whether or not such speecl was a matter of pubhc interest or concern); Miami Herald Publishing Co. v. Tornillo, 418 U.S. 241, 256 (1974) (invalidating a state's "right of reply" statute because it exacted a forbidden "penalty on the basis of the content of a newspaper").

19. In the prior restraint cases, of course, the regulations fell not on published material but rather on material of particular content of which pubhication was immimently contemplated.

20. Landmark Commumications, Inc. v. Virginia, 435 U.S. at 839.

21. Cox Broadcasting v. Cohen, 420 U.S. at 492. 
tion are values of independent constitutional significance entitled in their own right to the Court's solicitude.

Because they appear in cases which upheld traditional first amendment freedom from regulation aimed at the content of publication, however, the statements do not necessarily imply that public information or the informing function of the press is entitled in its own right to affirmative protection. Where government regulation of content is at issue, the question of independent constitutional significance for "the role of the press" does not necessarily arise since it is perfectly sensible to assume that the constitutional test of the validity of governmental sanctions on content is the saine whether the sanction is aimed at "speech" or "the press."22 The statements may be better read as a recognition that, by removing the threat of sanction, freedom from governmental regulation of content facilitates the dissemination of information to the public and supports the press in its role of providing information. ${ }^{23}$ But, while it is thus fair to say that freedorn is a necessary condition of public information and the existence of an informing

22. In Note, First Amendment Protection Against Libel Actions: Distinguishing Media and Non-Media Defendants, 47 So. CAL. L. Rev. 902 (1974), the argument was made that "media" and "nonmedia" speakers should be protected by different constitutional privileges. Until its decision in Gertz v. Robert Welch, Inc., 418 U.S. 323 (1974), however, the Court had never indicated that its first anendinent rules protecting communication fron cnt for individual communicators than they were for the press. In Gertz, however, Justice Powell's unajority opinion made references to such things as: "a publisher's constitutional privilege," 418 U.S. at 325 (emphasis added); "a newspaper or broadcaster that publishes," id. at 332 (emphasis added); "[a]llowing the media to avoid liabihty," id. at 340 (emphasis added); "self-censorship by the news media," id. at 341 (emphasis added); "the needs of the press," id. at 343 (emphasis added); "the communications media," id. at 345 (emphasis added). Even the holding was phrased in terms of "hability for a publisher or broadcaster," id. at 347 (emphasis added). After Gertz, Justice Stewart, in his provocative speech at the Yale Law School Sesquicentennial, seemed to assert that the libel cases from New York Times Co. v. Sullivan, 376 U.S. 254 (1964), through Gertz stood precisely for the proposition that the press was more heavily insulated from sanctions on account of the content of communications than were individuals: "[T]he Court has never suggested that the constitutional right of free speech gives an individual any immunity from liability for either libel or slander." Stewart, supra note 3 at 635 (cniphasis in the original). It remains sensible, however, to assuine that the constitutional test of the validity of governmental sanctions of communications whose content is protected is the sante whether the sanction is aimed at speech or the press. Justice Stewart's interpretation of the hibel cases cannot withstand analysis. See Shiffrim, Defamatory Non-Media Speech and First Amendment Methodology, 25 U.C.L.A. L. REv. 915, 92123 (1978). But see Bezanson, supra note 11. Moreover, the implicit suggestion of Gertz notwithstanding, the Court has never im fact extended either less or different protection to individuals on account of the content of speech than it has offered to the press on account of the content of publication. Recently, in Hutchinson v. Proxmire, 99 S. Ct. 2675, 2687 n.16 (1979), the Court mdicated that the issue is still open.

23. Upholding the freedom fron governmental regulation of the content of communication is likely, simply as a matter of common human experience, to advance the interest in public scrutimy and knowledge of governmental affairs and to support the press im its role of providing information to the public simce the absence of the threat of sanction makes it less costly for the press to provide information, thereby making it likely that the press will produce more information for the public to receive. 
press, it is not, as the access cases ${ }^{24}$ so readily demonstrate, a sufficient condition. Freedom from governmental sanction of content, in other words, does not guarantee a flow of information to the public nor does it assure that the press will be able to obtain information. The Court's invocations of these values im cases where they were threatened by affirmative regulations, therefore, may suggest that freedom's constitutional status is justified im part because it is imstrumental in promotimg them. ${ }^{25}$ It does not, however, necessarily imply either that tliese values share freedom's constitutional status or that they are entitled to independent, affirmative protection.

\section{B. The Right of Access and Privilege Cases}

Whatever imdependent constitutional significance ought to be attached to the Court's affirmations of the value of an informed public and the informing function of the press, it is at least clear that traditional doetrine has been responsive to the issues which the press free$\mathrm{dom}^{26}$ cases presented. They raised questions about either the contcnt of protected communications or the constitutional limits of governmental power to punisli or proscribe communication. Traditional doctrine has not been so plainly responsive either to the issues raised or, more fundamentally, to the premises of the claims made in cases in which the press has sought access to governmental information or protection against process requiring disclosure of information.

\section{The access cases}

Doctrimes about what speecll is protected and what direct sanc-

24. See text accompanying notes 27-54 infra.

25. It is, in fact, often asserted that first amendment rights are purely instrumental. See, e.g., Wellington, Common Law Rules and Constitutional Double Standards: Some Notes on Adjudica. tion, 83 YALE L.J. 221, 267 (1973).

26. As used herein, the term "freedom" denotes the absence of direct governmentally inposed, formal sanctions on particular activity and the reference to "press freedom" therefore denotes the absence of sanction on publication. This use of "frecdom," which restricts its meaning to its technical and traditional legal sense, should be carefully distinguished from a definition of "freedom" which wonld denote not the absence of formal governmental restraint on activity, but the governmentally guaranteed presence of effective power to engage in activity. Something like the latter conception of "freedom" has animated the provocative and influential argument that because the mass media have aceumulated too much power in the markctplace of ideas, the first amendment's guarantee of freedom of speech now includes a public right of access to the press. See, eg., Nimmer, supra note 3, at 645 ("speech can be effective and therefore free only if enhanced by devices such as a right-of-reply statute.") (emphasis supplied). See generally Barron, Access 10 the Press-A New First Amendment Right, 80 HARv. L. REv. 1641 (1967).

Commentators have recently begun to snggest that the first amendment secures "autonomy" to the press. See, e.g., Bezanson, supra note 11; Stewart, supra note 3. It does not appear froin their analyses, however, that "autonomy" denotes a different concept from formal freedoin from governmental restraint, punishnent, or coercion, despite the fact that the word may have inore suggestive connotations. 
tions the government may impose upon publication are unresponsive to the issues raised in the prison access cases-Pell v. Procunier, ${ }^{27}$ Saxbe $v$. Washington Post, ${ }^{28}$ and Houchins v. KQED ${ }^{29}$-and in last term's spectacularly controversial case upholding the closure of pretrial judicial proceedings, Gannett Co. v. DePasquale, ${ }^{30}$ for the simple reason that in none of them was any punishment imposed on account of the content of publication, there being no publications for the government to punish. It was not the right to publish, but rather the right to gather news from a government unwilling to supply. it which the press sought to establish. In Pell and Saxbe, the press souglit access to the prisons for the purpose of conducting interviews with specific individual inmates, claiming that "the accurate and effective reporting of news [about prisons] has a critical dependence upon the opportunity for private personal interviews." ${ }^{31}$ In Houchins, the press requested television cainera access to county jail facilities, contending that "access to penal institutions is necessary to prevent officials from concealing prison conditions from the voters and impairing the public's right to discuss and criticize the prison system and its administration." 32 In Gannett, the press asserted a right to attend a pretrial suppression hearing in order to fulfill the public's interest in being informed about the operation of the judicial system. In each of the cases the government acted-in the person of the prison administrators in Pell, Saxbe, and Houchins and of the trial judge in Gannett-to deny access but not to punisl1 the attempt to achieve it.

Pell, Saxbe, Houchins, and Gannett each involved the fundamental issue of whether the first amendment guarantees to the public a right to know in the forn of a right, enforceable either directly or through the agency of the press, to information within the government's control. The underlying premise of the press' claim in these cases was that access is constitutionally guaranteed to vindicate "the right of the people, the true sovereign under our constitutional scheme, to govern in an informed maimer." 33 If the press sought a "constitutional right of access . . . beyond that afforded the general public,"34 it was "not to enable [the press] to make inoney, not to set newsinen apart as a favored class, but to brimg fulfillment to the public's right to know"35 by informing

27. 417 U.S. 817 (1974).

28. Id. at 843 .

29. 438 U.S. 1 (1978).

30. 99 S. Ct. 2898 (1979).

31. Saxbe v. Washington Post Co., 417 U.S. 843, 853 (1974) (Powell, J., dissenting).

32. 438 U.S. at 13.

33. Pell v. Procunier, 417 U.S. $817,838-40$ (Douglas, J., dissenting).

34. Id. at 834 .

35. Id. (quoting Branzburg v. Hayes, 408 U.S. 665, 721 (1972) (Douglas J., dissenting)). 
the average citizen, who relies on the media for information.

In none of the cases, however, did the Court squarely confront the issue of whether the public has such a right to know. In Pell and Saxbe, Justice Stewart's opinions for the Court characterized the press' claims as urging a "special access" for journalists which the public at large did not enjoy. Implicitly seeming to assume that the governmental interests in maintaining prison discipline and security subordmated any right of "general" access, Justice Stewart sustained the regulations prohibitimg press interviews of specific minates with the opaque assertion that the government has no constitutional duty "to make available to journalists sources of information not available to the public generally." 36 This stroke trivialized the issue in the case by failing to meet the argument that denial of "special access" to the press infrimged the public's right to know. By contrast, in his dissenting opinion in Saxbe, Justice Powell agreed with Justice Stewart that journalists as individuals enjoy the same constitutional rights as their fellow citizens, yet argued im favor of special access for the press as "the necessary representative of the public's interest in this context and the instrumentality which effects the public's right." 37

Justice Stewart's characterization of the issue in Pell and Saxbe as involving no inore than a claim of preferential treatment avoided direct confrontation with not only the basic preinises of the press' claim, but also the imphications of his own rhetorical affirmations of the first ainendment's office in fulfilling the "broad societal interest in a full and free flow of information to the public."38 Justice Stewart las never explained how his Pell and Saxbe opinions square with his assertion in a later case that the press "has a constitutionally designated function of informing the public."39 But surely an explanation is in order: if the first ainendment ought to be read as vindicating a broad societal interest in a full and free flow of information to the public, and if the press has the constitutionally designated function of imforming the public, then it is hardly troublesome to find the press asserting a right of special access in order to vindicate society's interest and perform its own function.

It is difficult to avoid the conclusion that Justice Stewart's Pell and Saxbe opinions reject any notion that either the press or the public enjoys any right of access to governmental information. ${ }^{40}$ Still, Justice

36. Pell v. Procunier, 417 U.S. at 834.

37. Saxbe v. Washington Post Co., 417 U.S. at 864 (Powell, J., dissenting).

38. Branzburg v. Hayes, 408 U.S. 665, 725 (1972) (Stewart, J., disscnting).

39. Zurcher v. Stanford Daily, 436 U.S. 547, 572 (Stewart, J., dissenting).

40. As Justice Powell aptly pointed out:

From all that appears in the Court's opinion, one would think that any governmental restriction on access to information, no matter how severe, would be constitutionally 
Stewart's failure to confront either the premises of the press' claimwhich was based on the existence of a public right to know-or the clear implications of his own rhetoric-which would certainly seem to justify acknowledging the press' claim of special access-is troublesome for its lack of elaborative effort. ${ }^{41}$

Houchins v. KQED, Inc. presented the issue in sliarp relief. A television station challenged the denial of permission to make films and recordings in a county jail where conditions had become the subject of public controversy. The station argued that "from the right to gather news and the right to receive information" 42 arises an "implied special right of access to government-controlled sources of inforination." 43 Chief Justice Burger's opinion for the Court, signed by three justices, ${ }^{44}$ confronts somewhat more carefully than Justice Stewart's Pell and Saxbe opinions the implications of the press' argument, and offers some reasons why the Court ought to reject in principle a constitutional right to know. Assertimg that authoritative precedent to support the press' claim was lacking, ${ }^{45}$ and noting that a constitutional duty to dis-

acceptable to the majority so long as it does not single out the media for special disabili-

ties not apphicable to the public at large.

Saxbe v. Washington Post Co., 417 U.S. at 857 (Powell, J., dissenting).

41. In a speech at the Yale Law School Sesquicentennial Convocation on Nov. 2, 1974, which was reprinted in the Hastings Law Journal, Stewart, supra note 3, Justice Stewart adumbrated a theory that the "primary purpose of the constitutional guarantee of a free press was . . . to create a fourth institution outside the Government as an additional check on the three official branches." Id. at 634. To support his thesis, Justice Stewart cited and interpreted several of the Court's recent cases. Pell and Saxbe are cited, however, in support of a seemingly contrary proposition that "[t]here is no constitutional right to have access to particular government information, or to require openness from the bureaucracy." Id. at 636 . There is little analytical effort expended to explain what appears to be an inconsistency between what is described as a consciously chosen constitutional purpose to establish an imstitution to give "organized, expert scrutiny of government," $i d$. at 634, and what is asserted to be the absence "from the Constitution [of] any guarantee that it will succeed." Id. at 636.

42. 438 U.S. at 7.

43. Id. at $7-8$.

44. The Chief Justice and Justices White and Rehnquist. Justice Stewart concurred specially, and Justice Stevens, joined by Justices Brennan and Powell, dissented. Justices Marshall and Blackmun took no part in the case.

45. The lack of direct precedential support for the press' arguinent, however, ought not necessarily to have been determinative. First, the argument relied not on the direct force of precedent as such, but rather on inferences which the precedents supported in view of the Court's own rhetoric therem about "the importance of informed public opinion and the traditional role of a free press as a source of public information." 438 U.S. at 9. Second, the precedents had been set in cases in which the Court had resolved wholly different issues from those at stake in the clain of a public right of access to information. Grosjean v. American Press Co., 297 U.S. 233 (1936), for example, imvahidated a state tax on the advertising revenues of newspapers. Mills v. Alabama, 384 U.S. 214 (1960), invalidated a state statute which imposed criminal punishment on newspaper publications of editorials about election issues on election day. Branzburg v. Hayes, 408 U.S. 665 (1972), rejected the claim that newsmen have a qualified privilege to refuse to appear before grand juries. The press' fundamental claim that the first amendment protects the "right to know" raised a question about the values protected by the amendment which had never before been directly 
close "is contrary to statements in this Court's opinions," Justice proceeded to consider the question as an origmal matter and to reject the clain: ${ }^{47}$

Neither the First nor the Fourteenth Amendment mandates a right of access to governmental information within the government's control. Under our holdings in [Pell and Saxbe], until the political branches decree otherwise, as they are free to do, the media has no special right of access to the Alameda County Jail different from or greater than that accorded the public generally. ${ }^{48}$

The first sentence of the quoted statement, read in the context of the whole of the Chief Justice's argument, seems to signify an unqualified rejection of a right to know by three inembers of the Court. But the reference to the language of Pell and Saxbe in the second sentence stands in the way of such a resolute interpretation, and suggests that the Court's opinion may reduce to an affirmation of the requirement of evenhandedness which those cases inuposed. Justice Stewart's rather puzzling concurrence ${ }^{49}$ in the Houchins judgment echoes and extends Chief Justice Burger's broadest statement on the right to know issue, flatly asserting that

[t]he First and Fourteenth Amendments do not guarantee the public a right of access to information generated or controlled by government, nor do they guarantee the press any basic right of access superior to that of the public generally. The Constitution does no more than assure the public and the press equal access once government has opened

posed: whether the first amendment affirmatively and independently protects the value of a "wellinformed" citizenry, rather than merely derivatively securing the citizens' imterest in information by imposing negative restraimts on governmental regulation of publication. The answer to this question does not clearly or necessarily emerge either from prior doctrime designed to confront a different problem or from precedents which actually resolved very different issues.

Conversely, the fact that the Court had, in cases in whicl the issue was not clearly raised, made statements to the effect that the first amendment confers no public right to know ought not to foreclose the Court from giving articulate consideration to the issue in cases in which it is clearly raised. Thus, the Court's statements in Branzburg v. Hayes, 408 U.S. 665, 684-85 (1972), and Zemel v. Rusk, 381 U.S. 1, 16-17 (1965), negating the existence of any "unrestraimed right to gather information," 381 U.S. at 17, were nothing more than dicta on the issue of whether government has a duty to disclose information, since neither of these cases raised that issue.

46. 438 U.S. at 12.

47. Id. at 12-16. Among the reasous cited by Chief Justice Burger for rejecting the right to know were that "it invites the Court to involve itself in what is clearly a legislative task," id. at 12; that there is no support for the assumption "that media personnel are the best qualified persons for the task of discovering inalfeasance in public institutions," $i d$. at 13-14; and that there exists "no discernible basis for a constitutional duty to disclose, or for standards governing disclosure of or access to information," id. at 14.

48. Id. at 15-16.

49. The concurrence is puzzling because it suggests that the equal access whicl the Constitution guarantees does not necessarily translate into rights of access for the press whicls are identical to those granted to the public. This was the view of Judge Pregerson in the circuit court. 546 F.2d 284,286 (1976). 
the doors. 50

In Gannett Co. v. DePasquale, which involved the exclusion of the public and the press from a pretrial hearing in a inurder prosecution, the press contended that "inembers of the press and the public have a riglit of access to the . . . hearing by reason of the First and Fourteenth Amendments." N1 No claim of special rights of access for the press was involved. Justice Stewart, writing for the Court, declined to "decide in the abstract, whether there is any such constitutional right." $52 \mathrm{He}$ was, however, willing to assume, "arguendo, that the First and Fourteenth Amendments may guarantee . . .access in some situations," 53 though he found that "this putative right was given all appropriate deference" 54 by the state trial court.

Thus, in deciding Pell, Saxbe, Houchins, and Gannett, the Court accorded virtually no doctrinal significance to its own previous rhetoric affirming the first amendment substance of the values of an informed public and the role of the press in securing the flow of inforination. Yet, because these values were all that was at stake-there being in the cases no encroachment on freedom - the cases clearly raised the issue of whether an informed public and an informing press are values of mdependent significance which should be vindicated by tlie recognition of affirmative first amendment rights. The rlietoric affirming the value of an informed public and of the constitutional role of the press continues to appear in traditional press freedom cases in whicl the Court has upheld freedoun to publish by confining the range of governmental power directly to control the content of publication. Indeed, in many of its press freedoin opinions, the Court apparently has viewed freedom not as an end in itself, but as a ineans of securing an informed public and establishing the press in its informing role. Before decision of the access cases, it might have been plausible to infer that the Court was

50. 438 U.S. at 16 (Stewart, J., concurring in the judgment).

51. $99 \mathrm{~S}$. Ct. at 2911 (emphasis added). The case also involved a claimed sixth amendment right, which the Court rejected. Id. at 2901-11.

52. Id. at 2912 .

53. Id.

54. Id. Justice Powell's concurrence in the Gannett judgment, though agreeing that the Constitution liad not been violated by the trial court in that case, asked the Court to "hold explicitly that petitioner's reporter had an interest protected by the First and Fourteenth Amendments in being present at the pretrial suppression hearing." Id. at 2914. Justice Rehnquist's concurrence was at pains to assert a contrary proposition: "it is clear that this Court repeatedly has held that there is no First Amendment right of access in the public or the press to judicial or other governmental proceedings." Id. at 2918. Justice Blackmun's dissent, joined by Justices Brennan, White, and Marshall, was addressed.primarily to the sixth amendment claim. Justice Blackmun asserted that the sixth amendment contains sufficient guarantees of the right of access to judicial proceedings and that therefore le "need not reacli the issue of First Amendment access." Id. at 2940. Still, he stated that lie did "not agree" with petitioner's argument that the first amendment restricts closure of pretrial proceedings. Id. 
prepared to confer affirmative constitutional status on these objectives by recognizing their entitlement to protection as independent first amendment values. But such an inference cannot survive the access cases.

\section{The privilege cases}

The cases in which the press sought to protect its newsgathering and editorial functions froin governmental interference also posed, though not so directly nor im such pristine form, the basic issue presented by the access cases. The press privilege cases-Branzburg $v$. Hayes, ${ }^{55}$ Zurcher v. Stanford Daily, ${ }^{56}$ and Herbert v. Lando ${ }^{57}$-involved the constitutionality of grand jury subpoenas, third-party search warrants, and civil discovery orders issued against journahists or news organizations. The press did not challenge the procedures as direct assaults on the freedoin to publish. Rather, the heart of the claim was that application of the procedures to the news media would have such severe "chilling effects" on newsgathering or editing processes that the "flow of information" to the public would suffer intolerable detriinent. ${ }^{58}$ The implicit premise of the press' argument was that the flow of information to the public, which is dependent on the uninhibited performance of the newsgathering and editorial processes, is a value of constitutional dimension. Therefore, so the arguinent went, the newsgathering processes inust be protected froin indirect governmental interruptions even when the freedom to publish is not threatened. ${ }^{59}$

55. 408 U.S. 665 (1972).

56. 436 U.S. 547 (1978).

57. 441 U.S. 153 (1979).

58. E.g., Branzburg v. Hayes, 408 U.S. at 682 :

The claim is, however, that reporters are exempt from these obligations because if forced to respond to subpoenas and identify their sources or disclose other confidences, their infornants will refuse or be reluctant to furnish newsworthy information in the future. This asserted burden on newsgathering is said to inake compelled testimony from newsmen constitutionally suspect and to require a privileged position for them.

See also Herbert v. Lando, 441 U.S. at 194-95 (Brennan, J., dissenting); Zurcher v. Stanford Daily, 436 U.S. at 563-64.

59. This, of course, was also the foundation of the press' claim in the access cases. This common factor makes a discussion of both groups of cases necessary to answer completely the question whether first amendment doctrine extends independent protection to an informed public and an informing press.

Demial of the privilege because the fiow of information to the public is not a constitutionally protected value would seem to imply that there is no "right to know." Yet the privilege cases do not, as the access cases do, necessarily raise the right to know issue. See note 10 and accompanying text supra. The governmental action in the privilege cases tends to interfere with press attempts to gather and process infornation obtained from private parties. The access cases, on the other hand, involve the state's refusal to disclose information. In the former situation, the press invokes the first amendment as a shield, in the latter as a sword.

There are, of course, important fornal and analytical differences between the first amendment viewed as merely a set of negative restraints against governtnent and the ainendment viewed 
While the Court in each case rejected the press' argument that the "chilling effect" ought to be alleviated by the creation of quahified constitutional privileges for the press to be free from the offending procedure, the court did not directly reject the premise that the fiow of information to the public and the press' contribution thereto are values of independent constitutional significance. The Court did, however, exhibit an unusual degree of skepticism about the empirical validity of the argument.

In Branzburg, the press' claim that requiring newsreporters to testify before grand juries would deter sources of information froin talking with newsreporters had been carefully bolstered by empirical

as including affirmative governmental obligations. With respect to the fundamental question of whether the auneudment protects an informed public and an imforming press, however, it is useful to perceive that state "inaction" can impair those interests by denying reporters access to official information just as state "action" impairs them by deterring private persons from communicating with the press.

This is not to suggest that press privileges could not be justified on grounds other than that the Constitution in principle protects the values of an informed public, and an informing press. First, to exclude the possibility that special press rights exist in principle does not exclude the possibility that rules giving the press special rights might be legitimately justified by a conbination of principle and relevant praginatic and institutional concerns. Cf. Dworkin, The Rights of Myron Farber, N.Y. Rev. OF Books, Oct. 26, 1978, at 34 (press privileges not required by first amendment principles, but inay be justified by policy considerations). For a nore complete elaboration of the arguinent that constitutional rules may sometimes extend constitutional protection beyond the boundaries that strict principle would dictate, see BeVier, supra note 14, at 322-31. Second, the privilege cases do not, as the access cases do, present an issue devoid of any element of restraint on publication.

Indeed, the Court's rhetoric about the value of the flow of infornation to the public nay have so tumeled the analytical vision of both the press and the Court itself in the privilege cases as to have obscured the possibihty of characterizing in more traditional terns the values that the subpoenas and newsroom searches threatened. Both the thrust of the press' arguments and the concentrated focus of the Court's scrutmy were directed to the impact on the fow of news of the power to subpoena newsrepoiters and to search newspaper offices. Quite ignored, therefore, were the facts that the subpoenas in Branzburg and the searcls in Zurcher had followed directly upon and seened indeed to be consequences of the publication of information of clear political relevance. Given this context, the procedures became analogous to subsequent punishment of political speech and thus implicated press freedom to publisls in a rather direct way, wholly apart from the issues of whether "newsgathering" is a constitutionally protected activity or whether the indirect effect of the government's actions would in fact be to reduce the fiow of news to the public.

The analogy to subsequent punishment is not a perfect one, of course, since the government did not purport to sanction publication by threatening the press with loss of liberty pursuant to legislation proscribing publication of particular kinds of information. The analogy is apt, however, because in each of the cases pubtication of politically relevant information was followed by government action which clearly imposed costs upon the publication and thus rendered the publishing decision less free from and more susceptible to governmental coercion than it would have been had the power not existed to issue the subpoenas or conduct the search. Whether the Court would have found the analogy persuasive is not the poimt here. The point is that the Court's attention was never drawn to the coercive, freedom-threatening aspects of the clallenged procedures in Branzburg and Zurcher, no doubt in large part because rhetoric about the value of the fiow of infornation to the public and the constitutional role of the press in furnishing that information controlled the parties' perception of the values at stake and thus affected their characterization of the issues. 
studies to the effect that without the promise of confidentiality many sources of important news would refuse to talk to reporters. The Court acknowledged both that the argument that the flow of news would be constricted by requiring reporters to testify was not irrational, and that the record gave factual support to the clami. ${ }^{60}$ Still, it announced itself "unclear" about the extent to which informers would be deterred from furnishing information, and on that basis seemed to discount the weight of the argument for a press privilege. ${ }^{61}$

In Zurcher, the press contended that the issuance of a third-party warrant to search a newspaper office violated the first amendment because "searches of newspaper offices for evidence of crime reasonably believed to be on the premises will seriously threaten the ability of the press to gather, analyze, and disseminate news." 62 Urged to protect the flow of information from this indirect threat by requiring police to use a subpoena instead of a warrant, the Court again discounted the empirical validity of the press' argument, this time with its own empirical speculation that "[p]roperly administered, the preconditions for a warrant . . . should afford sufficient protection against the harms that are assertedly threatened by warrants for searching newspaper offices."63

In Herbert v. Lando, the Court deelined to rccognize a newsreporter's privilege in libel cases to be free from inquiry into "thoughts, opmions, and conclusions with respect to the material gathered by him and about his conversations with his editorial colleagues." 64 The Court

60. 408 U.S. at 693-95.

61. Id. at 693 . The analysis of the privilege cases in the text does not purport to be anything like a coinprehensive rendering of the Court's apparent rationales for rejecting the newsreporter's privileges or of the full range of issues of substance and process which the cases raise. The cases have generated a prodigious body of scholarly commentary. For example, the many substantive and procedural issues raised by Branzburg are comprehensively described and analyzed in Murasky, The Journalist's Privilege: Branzburg and Its Aftermath, 52 TExas L. Rev. 829 (1974). Those raised by Zurcher are best summarized in Note, Search and Seizure of the Media: A Statutory, Fourth Amendment, and First Amendment Analysis, 28 STAN. L. REv. 957 (1976). The Herbert case is most lucidly analyzed in Franklin, Reflections on Herbert v. Lando, 31 STAN. L. Rev. 1035 (1979), and Friedenthal. Herbert v. Lando: $A$ Note on Discovery, 31 Stan. L. Rev. 1059 (1979).

62. 436 U.S. at 563. The Court summarized the factual predicates of the argument as follows:

First, searches will be physically disruptive to such an extent that timely publication will be impeded. Second, confidential sources of information will dry up, and the press will also lose opportunities to cover various events bccause of fears of the participants that press files will be readily available to the authorities. Third, reporters will be deterred from recording and preserving their recollections for future use if such information is subject to seizure. Fourth, the processing of news and its dissemination will be chillcd by the prospects that searches will disclose interual editorial deliberations. Fifth, the press will resort to self-censorship to conceal its possession of information of potential imterest to the police.

Id. at 563-64.

63. Id. at 565 .

64. 441 U.S. at 158. 
did not reject the chilling effect argument in Herbert on empirical grounds. Rather, it reasoned that any chill on the editorial process or editorial decisionmaking which might flow from not recognizing the privilege is inherent $m$ the substantive standard of liability for defamation and thus has long smce been found to be constitutionally tolerable. ${ }^{65}$

The Court's rejection of the press' arguments in the privilege cases suggests more than skepticism about the arguments' empirical validity. The Court's readimess to discount the press' assertions that the privileges were necessary to secure the flow of information seems also to imply an unwillingness to accept the major premise of the chilling effect argument in the privilege context-that there is independent constitutional value in the flow of information. If this inference is a fair one, the combined force of the privilege and the access cases would seem thoroughly to undercut any argument that significant precedential support can still be mustered for a right to information within the government's control.

\section{PART II}

\section{CONSTitutional THeORY AND THE Right to KNOW}

The principal task of this Part is to evaluate, in terms of a constitutional theory of press freedom, the value of the flow of information to the public and the role of the press in furnishing that information. The precise question to be addressed is the validity of the fundamental but unstated premise of the rhetoric which affirms those values: Does the Constitution im primciple guarantee the public a right to know governmental information? If the inference of a constitutionally guaranteed right to know is not theoretically justified, there is scant constitutional foundation upon which to anchor either the value of an inforned public or the function of the press in providing infornuation. ${ }^{66}$

There are, of course, relevant distimctions between the right to know and the rights protected by traditional first amendment doctrime.

65. 441 U.S. at 171. Apart from the alleged chilling effect on free newsgathering and editing, the Court did express doubt as to the alleged chilling effect that liability for culpable error would have on error-avoiding procedures. The Court found it "difficult to believe that error-avoiding procedures will be terminated or stifled simply because there is liability for culpable error and because the editorial process will itself be examined in the tiny percentage of instances in which error is claimed and litigation ensues." Id. at 174.

66. Much of the debate over whether the press should have access to governmental infornation, proceedings, or facilities has consisted in arguunents for and against giving "special rights" to the press. See, e.g., Bezanson, supra note 11; Lange, supra note 3; Nimmer, supra note 3; Van Alstyne, Comment-The Hazards to the Press of Claiming a "Preferred Position," 28 Hastings L.J. 761 (1977). These arguments liave not posed the issue in terms of what seems to ine the inore fundamental question of whether "special press rights" can be adequately supported by the constitutional foundation of the right to know. This Article addresses that more basic question. 
Indeed, only because the government's failure to honor requests for information can be said to have meaningfully different impacts upon publisliers, and therefore to threaten different values from those necessarily at stake wlien publication itself is restrained or punished, is it useful to imquire whetler the riglt to know exists in primciple. For if infringement of a right to know were but another species of the threats to freedom posed by infringenent of the right to publish without punishment or restramt, then the right to know would raise issues of principle essentially identical to those raised in traditional first ainendment cases, and to isolate the right to know issue for separate theoretical inquiry would not be warranted.

The freedom to publisl relevant infornation about the activities of government is central to the protection afforded by the first amendment, and its protection is fully justified im primciple. ${ }^{67}$ The logical antecedent of the publication of information is, of course, the gathering of information. If, therefore, Congress were to atteinpt directly to restrain or punish the process of gathering information as such, the legislation would no doubt violate the first ainendinent. ${ }^{68}$ When the government denies to citizens or the press access to information it possesses, it neither directly restrains nor imposes punishment on the informationgathering process. However, the denial of access undoubtedly impedcs the process and thus constricts the ultimate flow of information to the public. The effect on the flow of information, therefore, of governmental denials of access to information is im that respect similar to the predictable effects of punishment or censorship. Nevertheless the failure of government to take affirmative action to remove the impediment caused by denial of access cannot be credibly argued to be the constitutional equivalent of punishment or censorship without ignoring important and traditionally significant differences between what are in fact two very disparate forms of governmental activity.

Demal of access to information has different consequcnces to a publisher than does punishment or prior restraint. The latter forms of regulation interfere quite directly with the freedoin to pubhsh. ${ }^{69}$ When the government denies access to information, however, it poses no threat to freedom, at least if that word is given its ordinary legal meaning. A publisher who fails to persuade the government to divulge its

67. See text following note 81 infra.

68. In Branzburg v. Hayes, 408 U.S. 665 (1972), the Court asserted that "newsgathering is not without its First Amendment protections." 408 U.S. at 707. Whatever else this statement can be taken to denote about the rights of newsreporters, it inust at least be read to support the statenent made in text.

69. A publisher who disobeys either a prior restraint or a penal statute will suffer a loss of personal liberty, while obedience to either entails a sacrifice of editorial freedom to choose to proceed with publication. 
secrets or to permit the public to enter and gather information about its prisons or its courtrooms does not risk criminal prosecution for making the attempt and remains quite at liberty to pursue other avenues to the information. Significantly, the publisher may give broad and embarrassing publicity to the government's denial of access, and will suffer no formal constramt in deciding to publish whatever information he is able to obtam from other sources than the government itself.

Perhaps inore important, governmental denial of access to inforination poses a different kind of direct threat to speech than do punishment and censorship, and thus the forms of governmental activity directly imphicate different values. Punishment or censorship directly undermine the value of free speech, while the denial of access to information undermines the value of well-informed speech. Free political speech may well serve the value of informed debate, ${ }^{70}$ but the only nievitable consequences of permittimg punishment or censorship of publication is loss of freedom. On the other hand, the only inevitable consequence of denial of access to governmental information is less information. Moreover. there is no basis for concluding that the consequently less informed political debate inust be less free, because governmental barriers to access to information neither themselves impinge upon freedom nor are they necessarily correlated with the presence of freedom-threatening sanctions.

In light of these distmctions, to conclude that it is unconstitutional for government to deny the public access to relevant information-that is, to conclude that there is a constitutional right to know-is to conclude that the first amendment in primciple vindicates, as of independent and affirmative constitutional significance, the value of wellinformed debate. And so to ask whether the Constitution justifies the inference of a right to know is but a way of asking whether, indeed, the Constitution guarantees that the public be well informed.

\section{A. Focusing the Theoretical Inquiry}

Any theory about the ineaning of a particular constitutional provision must be both guided and confined, either implicitly or explicitly, by an overarching general theory about the criteria for legitimate constitutional decisionınaking. ${ }^{71}$ The general criterion which guides and confines the theoretical inquiry of this Article is that constitutional rules are only legitimate if they are justified by primciples which are derived from the text of the document, from its history, and from the

70. See text accompanying note 23 supra.

71. Cf. Bork, supra note 14 (concern for legitimacy of constitutional adjudication inust inform all constitutional decisionmaking). 
structure of government it prescribes. ${ }^{72}$ A constitutional theory of press freedom will comprise a statement of the constitutionally derived normative value or principle agamst which every strand of constitutional doctrine concerning freedom of the press can be evaluated and with which each particular rule ought to be basically consistent. ${ }^{73}$ The principle must be forinulated in terms at least precise enough to be capable ex ante of guiding the decision of particular cases and post hoc of generatimg normative statements about results.

No such guiding principle emerges from the text of the first amendment; "for the words simply do not yield a simple exegesis." The text does supply words with whose many possible meanings any admissible interpretation must be consistent. ${ }^{75}$ Those with which we are primarily concerned secure "freedom . . . of the press" from any "law abridging" it. The language seems to secure citizens agamst coercive governmental interference rather than to require the government to conduct its busmess opeuly. It is language which is technically illdesigned to impose upon government the affirmative obligation to disclose its affairs which must be the correlative of a "right to know." One could, however, argue that a linguistically permissible rendering of the terin "freedom . . . of the press" would imclude "freedom" even from the kind of indirect "abridgment" which ensues any time any governmental busimess is conducted in secret. ${ }^{76}$ Because it does not give to the words a meaning which they will not bear, the inference that the text of the first amendment confers a "right to know" cannot be rejeeted out of hand. Still, because such an inference straims the text, perhaps the contrary inference that the text merely confers rights agamst direct, positive encroachments ought to be preferred.

History is both as elusive and as suggestive on the "right to know" question as it is on all of the questions of contemporary relevance which the framers did not specifically address. ${ }^{77}$ Not having had to

72. For an exposition of the premises which support this criterion, see BeVier, supra note 14, at 304-06.

73. For an example of the relationship between principles and rules in the first amendment area, and an argument that first amendment rules which extend protection beyond what strict principle would require are sometimes justified by pragmatic and institutional concerns, see $i d$. at $322-43$.

74. Id. at 309.

75. Cf. id. at $306 \mathrm{n} .28$ (words in text must not be given a meaning they will not bear in ordinary discourse).

76. As used in this Article, however, "freedoun" denotes the absence of formal governmental sanction. See note 26 supra.

77. The historical analyses of those who have approached the issues addressed in this Article by asking whether the Constitution provides special protection for the press have yielded differing conclusions. Compare Lange, supra note 3, at 88-99 (framers used "speech" and "press" interchangeably) with Stewart, supra note 3, at 633-35 (framers intended to protect the press as an institution). The fact that historical analysis is a seductive, potentially misleading, and usually 
confront the argument that the Constitution in principle guaranteed citizens access to the internal workings of the government, the framers cannot be said either to have accepted or rejected the proposition in terms clear enough unalterably to confine today's choices. Historical practice suggests, however, that the framers did not think it illegitimate to conduct important governmental affairs in confidence. ${ }^{78}$

In the absence of significant aid from text or history, one is left to reason from the structure of government prescribed by the Constitution about whether a right to know can be justified in principle. Structural analysis is not inherently more likely than textual exegesis or historical analogy to generate consensus. ${ }^{79}$ In the first amendment area, however,

inconclusive or debatable ineans of deriving constitutional principles is not open to question. The point has often been made in the hiterature, but nowhere more brilliantly than by Professor Bickel. A. Bickel, The Least Dangerous Branch 98-110 (paperback ed. 1962). The specific assumption underlying the historical analysis in this Article is that, if it is apparent that the framers did not inake a deiberate and conscious choice to foreclose the possibility that the Constitution would be interpreted to confer a right to know, and if one thinks "it more likely than not that the framers wanted to delegate to us . . . the decision what rule should govern these kinds of cases," Blasi, Book Review, 80 YALE L.J. 176, 191 (1970), we remain free to decide the question for ourselves.

78. The secrecy of the constitutional convention is perhaps the most obvious example of the implicit recognition of both the practical necessity of and the absence of principled objections to closing the doors of at least certain governmental processes to citizens. Less well known is the fact that the Senate itself conducted its business behind loeked doors until 1795. Until quite recently there has never been a challenge in principle to the government's "right to withhold" information. Even today, when governmental secrecy is being subjected to constitutional attack, no one seems seriously to assert that the Constitution invalidates the great variety of informal methods by which governmental processes have always been kept confidential: "by selection of trustworthy personnel, by rules, practices, and mores of nondivulging, by avoidance of written communication, . . . by classification and restricted distribution, by codes and ciphers, by locks and guards." Henkin, The Right to Know and the Duty to Withhold: The Case of the Pentagon Papers, 120 U. PA. L. REv. 271, 273 (1971).

It might be argued that, given the obvious absurdity of mounting a serious constitutional challenge to these informal means of governmental nondisclosure, they are irrelevant to any consideration of the right to know question. In response, however, it seems fair to point out that there is certainly no reason in principle why a constitutional right to know would not at least prima facie invalidate these informal devices for retaining confidentiality. And even if it is absurd to accuse anyoue of having suggested that the Constitution renders sucls practices suspect, it is well to reneenber that "the absurd has its uses in law . . . . [1]t suggests the sweep of casually accepted values and focuses attention on the interveuing principles and devices that keep certain values ... from overwhelming other values that call for differentiation." B. SCHMIDT, FREEDOM OF THE Press vs. Public ACCESS 19-20 (1976).

79. Analysis which attempts to derive constitutional principles from the structure of government prescribed by the Constitution cannot lay claim to having found a truth that is necessarily unore "objective" or more likely to command universal assent than any other method of analysis. There are, however, powerful reasons to assay structural analysis. The first is that the Constitution itself is the only source of legitimate constitutional principles, and it is the Constitution itself which provides the anchor for structural analysis. A second reason is that explicit structural analysis requires that premises be divulged and thus makes it more likely that issues can more effectively be joined and areas of apparently basic disagreeınent explored for common ground.

The structural analysis that follows in the text is speculative rather than definitive, and its couclusions are offered tentatively rather than with absolute conviction. The analysis is more an attempt to ask some of the right questions about the fundamental implications of assigning consti- 
there is one principle which both commands widespread agreement and is derived from constitutional structure: the core first amendment value is that of the democracy embodied in our constitutionally estabhished processes of representative self-government. ${ }^{80}$

This statement of a fundamental first amendment premise is an appropriate starting point in the search to discover whether a right to know governmental information can be justified by a constitutional theory of press freedom. ${ }^{81}$ To questions about whether the contents of particular communications fall within the first annendment's ambit, and about the scope of governmental power to regulate speech or publication, the above principle readily yields the conclusions that "pohtical speech" is the amendment's central concern and direct governmental constraints of such speech the subject of its prohibitions: freedom to discuss political issues, to engage in pohtical debate, and to disseminate information about the affairs of government without governmental restraint, coercion, or threat of pumshment is quite obviously essential to democratic government.

But the principle requires substantial elaboration and refinement before it can generate similarly unequivocal answers to the question whether the public has a constitutional right to know governmental information. As to this question, the statement of principle is insuffciently precise because it does not specify whether the democratic

tutional value to an informed public and an informing press than it is a completely confident set of assertions about what our constitutional democracy necessarily implies about the right to know. Still, looking at the right-to-know issue from the perspective offered here generates conclusions which seem worth suggesting, both because they can be justified in principle and because they yield a theory which explains and legitimates much of present doctrine.

80. The seminal work relating the first amendment to self-government is that of Alexander Meiklejohn. See, e.g., A. Meiklejohn, PolitiCal Freedom (1948). Although there does seem to be a consensus that the first amendment provides vital support for constitutional democracy, it should be noted that commentators describe first amendment democratic values in various ways, focus their analyses on different doctrinal isues, and reach divergent conclusions. Compare Redish, The First Amendment in the Marketplace: Commercial Speech and the Values of Free Expres. sion, 39 GEO. WASH. L. REv. 429 (1971) (arguing that informational commercial speech furthers first amendment values because, inter alia, self-government is premised on a belief in the integrity of the individual intellect), with Blasi, supra note 11 (arguing, inter alia, that the value of frec speech and a free press in checking the abuse of power by government officials grows out of democratic theory but has different premises from the self-government value supported by traditional first amendment doctrine).

81. This Article does not address the question of whether the right to know could be justified under a theory of the first amendment that specifies as central to the amendment's concern, values other than those inherent in constitutionally prescribed deınocratic processes. See, e.g., Emerson, Toward a General Theory of the First Amendment, 72 YALE L.J. 877, 878 (1963) ("individual selffulfillment" as a core first amendment value). It should be noted that even those theories which proffer other values as key to first amendment analysis concede that the free expression of political opinion is of great importance. See, e.g., id. For development of the argument that the amcndment's protection is appropriately limited to pohitical speech, see BeVier, supra note 14; Bork, supra note 14. 
processes envisioned by the Constitution are those which necessarily imply affirmative, judicially enforceable governmental obligations to disclose information. Without further analysis, therefore, the statement of principle that the first amendment protects constitutionally established processes of representative self-government does not support the conclusion that the Court's rhetorical affirmations of the values of the public being informed about government and of the press' role in bringing such information to the public ought to be conceived of as acceptable elaborations of constitutonal principle.

\section{B. Representative Democracy and the Right to Know}

The arguments for recognition of a right to know in principle claim to draw sustenance from the democratic processes prescribed by the Constitution. ${ }^{82}$ The arguments seem to be based on three implicit premises about those processes. The first premise is that the processes quite literally embody the concept of "self-government" in the sense of constitutionally invitimg direct citizen oversight of -if not, indeed, participation in - the daily affairs of government. The Constitution therefore entitles the citizen to access to "all relevant information." The second premise is that there is a normative standard, derived from the constitutionally prescribed democratic processes, against which claims of entitlement to particular kinds of information can be properly evaluated. The third premise is that the task of deciding what information the government must reveal is not appropriately performed by the democratic processes themselves but rather has been constitutionally committed to the courts. Analysis of the arguments in favor of the right to know apropriately begins with a consideration of the validity of each of these three premises.

\section{Effective self-governance}

The conception of democracy apparently embraced by proponents of the "right to know" echoes the views of Alexander Meiklejohn, whose imsights into the relevance of self-government to first amendment analysis have been of seminal importance. "The principle of the freedom of speech springs from the necessities of the program of selfgovernment," 83 he reasoned. "It is a deduction from the basic American agreement that public issues shall be decided by universal suf-

82. See, e.g., Klein, Towards an Extension of the First Amendment: A Right of Acquisition, 20 U. MiamI L. Rev. 114 (1965); Parks, The Open Government Principle: Applying the Right to Know Under the Constitution, 26 GEO. WASH. L. REv. 311 (1971); Note, Access to Official Information: $A$ Neglected Constitutional Right, 27 IND. L.J. 208 (1952) [hereinafter cited as Neglected Constitutional Right]; Note, Access to Government Information and the Classification Process-Is There a Right to Know?, 17 N.Y.L.F. 814 (1971).

83. A. MEIKLEJOHN, supra note 80 , at 27. 
frage."84 Meiklejohn initially addressed the question whether the clear and present danger doctrine, or any other doctrine that would sustain legislation punishing political speech on grounds of national security, was constitutionally permissible. ${ }^{85}$ Focused as he was on issues of freedom, Meiklejohn did not specifically consider whether the Constitution confers a right to know on individual citizens.

Yet his conception of the relationship between constitutional democracy and the first annendment provides substantive and rhetorical support for the implication of a right to know. For example, Meiklejohn maintained that "[n]o suggestion of policy shall be denied a hearing because it is on one side of the issue rather than another"86 since "[w]hen men govern themselves it is they-and no one else-who must pass judgment upon wisdonr and unfairness and danger." elaborating his argument he asserted that "[j]ust so far as, at any point the citizens who are to decide an issue are denied acquaintance with information or opinion or doubt or disbehef or criticism which is relevant to that issue, just so far the result inust be ill-considered, ill-balanced planning for the general good." 88 This stateinent, made in specific support of the proposition that government inay not deny citizens the right to express relevant ideas, also seems to support the quite different proposition that government may not deny citizens access to relevant inforination.

Meiklejohn's view of constitutional democracy and the nature of citizenship also surfaces in his discussion of Justice Holmes' opinion in the Abrams $^{89}$ case:

The First Amendment's purpose is to give every voting member of the body politic the fullest possible participation in the understanding of those problems witl which the citizens of a self-governing society must deal. When a free man is voting, it is not enough that the trutl is known by someone else, by some scholar or administrator or legislator. The voters must have it, all of them. The primary purpose of the First Amendment is, then, that all the citizens shall, so far as possible, understand the issues which bear upon our common life. That is why no opinion, no doubt, no belief, no counter-belief, no relevant information, may be kept from them. Under the compact upon which the Constitution rests, it is agreed that men shall not be governed by others, that they shall govern themselves. ${ }^{90}$

84. Id.

85. He concluded that the first amendment "established an absolute, unqualified prohibition of the abridgement of the freedom of speech." Id. at 20.

86. Id. at 26-27.

87. Id. at 27.

88. Id.

89. Abrams v. United States, 250 U.S. 616 (1919).

90. A. MEIKLEJOHN, supra note 80, at 75. 
It is but a short step from this view of "self-government" and the related purpose of the first amendment to the conclusion that "every citizen has a constitutional right to obtain all [government] information." 1 The reverberations of Meiklejohn's analysis of democracy are quite unmistakable; indeed, in the justification offered for the right to know by Professor Emerson: "The public, as sovereign, must have all information available in order to instruct its servants, the government. As a general proposition, there can be no holding back of information; otherwise, ultimate decision-making by the people, to whom the function is committed, becomes impossible." 92

The difficulty with the view of "self-government" which is imphicit in the assertions of both.Meiklejohn and Emerson is that the delnocratic processes enbodied in the Constitution prescribe a considerably more attenuated role for citizens in the actual decision of public issues. Whereas Meiklejohn deduces from the basic American agreeinent of self-government that "public issues shall be decided by universal suffrage," 93 it is surely more accurate to describe that agreement as being that public issues shall be decided by representatives of the people who shall be elected by universal suffrage. The "town meetimg" analogy upon which Meiklejohn relies so often im his analysis of the relationship of freedom of speech to democracy ${ }^{94}$ is simply not an apt description of the structure of democracy prescribed by the Constitution. Of course, the Constitution establishes a "popular government," one in which ultimate sovereignty resides in the people and which we are rightly accustomed to thinking of as "democratic." But it is a representative democracy rather than a direct democracy which the Constitution contemplates. The Constitution envisions, in other words, a system in which the citizens do not directly either make or implement public decisions, though through their power to elect their representa-

91. Emerson, Colonial Intentions and Current Realities of the First Amendment, 125 U. PA. L. Rev. 737, 755 (1977).

92. Emerson, supra note 10 , at 14. The Meiklejohn view of self-government which Professor Emerson echoes also reverberates in the rhetoric in Court opinions concerning the value of wellinformed citizenry and the concounitant virtues of the informing function of the press. See, e.g., Houchins v. KQED, Inc., 438 U.S. 1, 32 (1978) (Stevens, J., dissenting) ("Without solne protection for the acquisition of information about the operation of public institutions . . the process of self-governance contemplated by the Framers would be stripped of its substance."); Saxbe v. Washington Post Co., 417 U.S. 843, 862-68 (1974) (Powell, J., dissenting) (first amendment " is one of the vital bulwarks of our national commitment to self-government.' . . By enabling the public to assert meaningful control over the pohitical process, the press performs a crucial function im effecting the societal purpose of the First Amendment."); Pell v. Procunier, 417 U.S. 817, 839-40 (1974) (Douglas, J., dissenting) (press, in gathering information, vindicates "the right of the people, the sovereign under our constitutional scheme, to govern in an informed inanner.").

93. A. Meiklejohn, supra note 80, at 27.

94. Id. at 24-28. 
tives they retain their authority to choose the direction of governmental policy.

Indeed, the Constitution was specifically structured by the founders so as to avoid the well-known "excesses" of the "pure democracy" model. ${ }^{95}$ It was thought that even the directly elected representative model did not provide adequate safeguards agamst such democratic excesses. Thus, while Representatives are elected to the House proportionate to population, ${ }^{96}$ Senators are elected two per state regardless of the state's population. ${ }^{97}$ The President, moreover, is not, technically, even directly elected by the people but through the electoral college, whose members are elected by the people. ${ }^{98}$ To the states the Constitution guarantees not direct democracy, but a "republican form of government." When one considers that the other major institutions of governmental power, members of the judiciary and heads of administrative agencies, are appoimted by elected representatives of the people but not directly elected, it becomes even more apparent that the "town meetimg" model of American government is an inexact and mappropriate basis for analysis. ${ }^{100}$

To the extent, therefore, that the inference of a "right to know" depends on a view of self-government which misconceives the nature of constitutionally prescribed popular sovereignty, it is not an inference which can properly be drawn from the processes of democratic government prescribed by the Constitution. Since the Constitution does not establish a direct democracy, the inference of a right to know cannot find its constitutional source in the view of popular sovereignty which contemplates direct citizen participation in the making and administration of laws.

\section{A constitutional norm}

The second premise of the structural argument for a right to know, which does not depend for its validity on any notion of direct democracy, loolds that there can be derived from the constitutionally prescribed democratic processes a normative standard agamst which particular claims of entitlement to government information can, at least prima facie, be evaluated. The notion seems to be that the Constitution itself prescribes an objectively knowable amount and kind of information which citizens must have "if democracy is to work." 101 Disclosure

\footnotetext{
95. See, e.g., The Federalist No. 10 (J. Madison).

96. U.S. CoNST. art. I, \& 2, cl. 3.

97. Id. $\S 3$, cl. 1.

98. Id. art. II, $\S 1$.

99. Id. art. IV, \& 4.

100. See generally The Federalist Papers.

101. Emerson, supra note 10, at 14.
} 
by the government of this quality and quantity of information will "achieve effective public knowledge of all that should be known." 102 Because the premise that there is such a normative standard is implicit, right-to-know proponents have not been careful to articulate its content. But a normative standard which readily suggests itself is that of "relevance": if a citizen seeks information which can fairly be said to be "relevant to self-government," the citizen has a constitutional right to have the information revealed. ${ }^{103}$

Speeches or publications containing relevant information are, of course, the clearest exainples of "political speech" protected from direct sanction by the first amendment. And certainly citizens possessed of the franchise have a legitimate and understandable interest in knowing what their government is doing, even if their only constitutional right to participate in government decisions and activities is that of voting periodically for persons to represent them. The standard of relevance is therefore beguilingly appropriate as the measure of the legitimacy of a citizen's claim to government information.

Even the most ardent supporter of the right to know, however, would probably not wish to assert that, in order to make meaningful use of the franchise, one citizen or all citizens either have a need to know every scrap of conceivably relevant information about government or, if they had every scrap, could make anything like effective use of it. Conversely, even the most ardent defender of government's prerogatives of secrecy and confidentiality would be hard put to inaintain that citizens can effectively evaluate and thus sit in electoral judgment of their representatives if the government's affairs and decisioninaking processes are completely shielded from public scrutiny. It seens far from radical to assert that the amount of even relevant information about government which a "well-informed" citizenry "ought" to have is considerably less than all which exists, considerably more than none.

But how much is enough? And by what criteria is the scope of government's duty to disclose to be measured? On the issue of how much information is enough, the standard of relevance is beside the point: "relevance" goes only to the question of whether the information is germane, not to the separate question of whether enough of it has been disclosed to "make democracy work." We can readily admit

102. Henkin, supra note 78 , at 278 .

103. Professor Emerson is apparently persuaded that since most information in the hands of government is likely to be "relevant," citizen claims for access should be honored. Einerson, supra note 10 , at 16. He questions, however, whether courts ought to be entrusted with the task of determining whether particular information is relevant, fearing that to permit courts to perform such a task would sanction the regulation of "expression on the basis of its content. It is not the prerogative of government to decide whether any communication is good or bad, useful or dangerous, needed or not needed." Id. at 22. 
that all information in the hands of government is relevant to "selfgovernment" without necessarily in any way implying that unless each citizen possesses all such information, the opportunity which the Constitution gives him to exercise the franchise is rendered meaningless, a sham. Yet we enter the realm of pure speculation if we attempt to conceive of an objective measure of how much information about government would be possessed by "well-informed" citizens of a functional democracy. ${ }^{104}$

The Constitution provides neither explicit nor implicit guidance about how to answer the question whether in any particular situation there is "effective public knowledge of all that should be known."105 This fact suggests that it is futile to attempt to derive from that document a normative standard for determining how much information about government is the "right amount." It also implies that the issue itself has been left by the Constitution to be determined in the political marketplace.

\section{The role of the courts}

The third premise of the argument that a right to know exists im principle rejects this implication and holds that the task of deciding what information the government must reveal has been constitutionally committed to the courts rather than to the democratic process. This view is im a sense but a corollary of the second premise that there can be derived from the Constitution a normative standard for measuring how mucl 1 and what kind of information must be revealed. It seems likewise misconceived.

In the first place, the representative democracy established by the Constitution commits the making and implementation of governmental policy not directly to the people themselves but to their elected representatives. For the policy choices they make, the representatives are ultimately accountable to the people. Deciding whether governmental information shall be freely available or severely restricted, or whether governmental facilities shall be open to public inspection or closed, is so integrally related to the legislative and executive functions as to

104. Research has not even addressed the question of how much, or what kinds of, political information would be optimal for purposes of facilitating the workings of a democracy. Some research, however, done in the area of consumer information, demonstrates the difficulty of attempts to determine the appropriate kinds and optimal flow of information to consumers because of the complexity of the purchase decision process. See, e.g., FEDERal Trade Commission, CONSUMER INFORMATION REMEDIES (1979). Certainly the process of pohitical decisionmaking is more complex than consumer purchase decisions, and, by analogy, determining the optimal amount of information for voters would prove even more difficult.

105. Henkin, supra note 78 , at 278. 
compel the conclusion that the Constitution has committed these choices not to the people themselves but to their representatives.

Considering the whole of the constitutionally prescribed process of representative democracy, it is sound to infer that the people do not have the constitutional right to demand through the courts that their representatives choose to disclose information, which is what recognition of a right to know would give them. They do have the constitutional right to affect the choices that their representatives make on the issue of public disclosure, because they possess the franchise and are thus constitutionally entitled to bring political pressure to bear on the resolution of the issue and to hold their representatives accountable when the choices they make are pohtically unacceptable. In recent years, of course, the political pressures toward openness which citizens have put upon their representatives have proved increasingly irresistible. ${ }^{106}$

The premise that the Constitution has committed not to the political processes but to the courts the task of finally deciding what information the government must reveal to its citizens is unsound for a second reason. The absence of a constitutionally derived normative standard by which to evaluate particular claims to information renders such questions inherently incapable of yielding primcipled results, yet susceptibility to principled resolution alone justifies committing them to the courts for resolution. ${ }^{107}$

Even assuming, however, that the governing normative value which justified the right to know could be described so as to yield a principle - that of a well-informed citizenry, say, possessed of sufficient amounts of relevant information about government to make democracy work-insurmountable difficulties would remain in the way of principled resolution of actual cases. Whereas the effective vindication of such a principle would require its translation into a well-nigh absolute right at least presumptively entitled to prevail over all governmental defenses except those erected against the release of irrelevant information, no governinent could function under the constraints of having to honor every request of every citizen for information. The right to know, therefore, would have to be bounded in principle by governmen-

106. The effects of such pohtical pressure is evident in federal and state "Freedom of Information" and "Government in the Sunshine" legislation. See, e.g., Freedom of Information Act, 5 U.S.C. § 552 (1976); Government in the Sunshine Act, Pub. L. No. 94-409, 90 Stat. 1241 (1976); Freedom of Information Law, N.Y. PUB. OFF. LAw $\$ \$ 84-90$ (McKinney Supp. 1979); Virginia Freedom of Information Act, VA. CODE $\$ 2.1-340$ to 346.1 (1979).

107. It is, at least, a basic premise of this Article that the demand that constitutional decisions be legitimate requires that they rest upon a foundation of primciple. For further elaboration of this view, see BeVier, supra note 14, at 304. See generally, e.g., A. BICKEL, supra note 77. 
tal necessity, since no constitutional principle ought logically and inevitably to entail a fatal sacrifice of government's basic viability.

Yet it is impossible to conceive of a court making case-by-case deterininations of the "necessity" of nondisclosure in any way that would bear even the faintest resemblance to the "reasoned elaboration" of principle which ought to characterize the judicial inode. The legitimate necessities of governmental operations would be threatened by requests for inforination in ways so inultifarious, so complex, and so much a product of practical and prudential considerations that to purport to evaluate thein in terins of "principle" would be worse than misleading. The rhetorical skepticism of Professor Henkin seems fully justified: "Can courts ineaningfully weigh the Government's 'need' to conceal, the Press' 'need' to publish, the people's 'need' to know? . . . How does the Court weigh the people's 'need' to know in any particular case?"108

Of course judges can purport meaningfully to weigh these needs by a process that has many of the earinarks of the kind of case-by-case balancing of competing interests that necessarily characterizes the process of deciding many first amendment cases. The dissenting opinion of Justice Powell in Saxbe, for example, seems to be the product of a judicious, sensitive, and particularized analytical effort to adumbrate the parameters of the right to know within the narrow confines of the facts of a particular case. Justice Powell attempted, if not precisely to weigh the people's need to know, at least to mdicate the respects in which he deemed it weighty. ${ }^{109} \mathrm{He}$ atteinpted to evaluate the justifications for the government's "need" to conceal ${ }^{110}$ and even to assess the press"

108. Henkin, supra note 78, at 278-79. Justice Brandeis, in arguing that respect for the institutional limitations of courts was among the reasons why the Court had been misguided in granting the Associated Press what ainounted to a property right in the news, articulated soine of the strains which the recognition of a new private right necessarily places upon the judicial process. International News Serv. v. Associated Press, 248 U.S. 215, 262-67 (1918) (Brandeis, J., dissenting). His observations retain their timeliness and seem apt to the right to know:

[T]o give relief. . . would involve inore than the application of existing rules of law to new facts. It would require the making of a new rule in analogy to existing ones. The unwritten law possesses capacity for growth and has often satisfied new deinands for justice by invoking analogies or by expanding a rule or principle. ... Where the problein is relatively simple, as it is apt to be when private interests only are involved, [this process] generally proves adequate. But with the increasing complexity of society, the public interest tends to become omnipresent; and the problems presented by new demands for justice cease to be simple. Then the creation or recognition by courts of a new private right may work serious injury to the general public unless the boundaries of the right are definitely established and wisely guarded. In order to reconcile the new private right with the public interest, it may be necessary to prescribe limitations and rules for its enjoyment; and also to provide administrative machinery for enforcing the rules.

Id. at 262-63.

109. 417 U.S. at 861-64 (Powell, J., dissenting).

110. Id. at $864-70$. 
need for the particular kind of information to which it sought access. ${ }^{111}$ And all of this evaluation seemed to proceed under the umbrella of a unifyimg theory:

What is at stake here is the societal function of the First Amendment in preserving free public discussion of governmental affairs .... [P]ublic debate must not only be unfettered; it must also be informed. . . . An informed public depends on accurate and effective reporting by the news media. . . . In seeking out the news the press ... acts as an agent of the public at large. . . The underlying right is the right of the public generally. The press is the necessary representative of the public's interest in this context and the instrumentality which effects the public's right. ${ }^{12}$

Close scrutiny of the Saxbe dissent, however, reveals that even a judicious, sensitive, and particularized analysis, when it refuses to specify the constitutional criteria which guide it (because such criteria are in fact nonexistent), cannot be the effective equivalent of the reasoned elaboration of principle. Justice Powell, for example, indicated his unwillingness to "follow the right of access argument as far as dry logic might extend," 113 but he only hinted at the nature of the limits beyond which he concluded that logic ought not to proceed ${ }^{114}$ and he failed utterly to suggest why, im any event, the right of access to governmental information ought not in primciple to be extended to its logical limits. Moreover, the careful weighing and the sensitive evaluation of the competing interests proceed quite without the guidance of any objective or consistently apphicable standard by which Justice Powell claims to have identified the imterests involved, much less any criteria by which he measured or compared their weights.

Justice Powell's opmion presents itself as a narrow resolution of a particular controversy, disclaiming any imtention "to suggest that the government must justify under the strimgent standards of first amendment review every regulation that might affect in some tangential way the availability of inforination to the news media."115 Insofar as it represents an effort to limit the potential sweep of judicial power if the Court recognizes a right to know, the disclaimer is both ineffectual and misleading. It is misleading because the issue is not whether the Court should engage in "strict" or "minimal" scrutiny of government regulations that restrict the availability of information. Rather, the issue is whether the Court should subject such regulations to any scrutiny at all. It should do so only if there is an enforceable constitutional right to

111. Id. at 853-56.

112. Id. at 864 .

113. Id. at 860 .

114. Id. at 860-61.

115. Id. at 860 . 
information within the government's control. To characterize the debate as having to do merely with the standard of review assumes that there is such a right and thus unduly minimizes the fundamental significance of the controversy.

Justice Powell's disclaimer of an intent to engage in strict scrutiny of every governmental regulation which restricts the flow of information is also ineffectual to lessen the reach of federal judicial power that is inescapably inherent in the decision that there is a constitutional right to know of any dimension. Implicit in such a decision, even if it is couched im language both cautious and deferential, is the result that the ultimate power to decide, as a matter of constitutional law and first amendment primciple, whether government must reveal information to the public resides, im every case, with the Court. This result is one which, as the previous arguments have attempted to demonstrate, the very nature of the question does not warrant.

The fact that, in cases like Gannett, it is courts that decide in the first instance whether trials should be open or closed does not make vindication of the right of access to judicial proceedings a less intrusive exercise of the Court's power. If the Supreme Court decides that there is a first amendment right to attend judicial proceedings, the right of state courts to make closure decisions based on state law ${ }^{116}$ would necessarily yield to the ultimate power of the Supreme Court to decide cases of public access on federal constitutional primciples. The important issue is whether such constitutional principles exist, and this issue is present whether the decision to deny access is made by state courts or federal prison authorities.

\section{An Informed Public, the Political Process, and Freedom of the Press}

To conclude that the question of how much imformation the government must release to its citizens is not susceptible to principled reso-

116. The basis for a state court's closure of its proceedings can be in a state statute. For instance, in Richmond Newspapers, Inc. v. Commonwealth, 5 Med. L. Rep. 1545 (Va.), cert. granted, 100 S. Ct. 204 (1979), the Virginia Supreine Court upheld a trial court's decision to exclude the press and the public froin a inurder trial when the request for closure was made by the defendant and after the court had previously declared several mistrials in the case based upon pubhcity problems. The trial court based its decision on a state statute, VA. CoDE \$ 19.2-266 (Supp. 1979), which provides that "the court unay, in its discretion, exclude from the trial any persons whose presence would impair the conduct of a fair trial, provided that the right of the accused to a public trial shall not be violated." Alternatively, the state court closure of its proceedings can rest upon the general common law power of state courts to control their own procedure in cases involving state law, absent constitutional constraints. Regardless of whether state court closure is based upon a state statute or upon the state court's common law powers, before federal courts can legitimately interfere with ordinarily autonoinous state court procedure, a constitutional principle justifying such intervention must be found and delineated. 
lution and is therefore committed to the political branclies is to embrace the possibility of a wholly unpredictable outcome in terms of how much and what kind of information will be divulged. Resolution will depend not upon the disinterested application of an allegedly objective standard of how much information "ought" to be disclosed. Rather, resolution will emerge froin a dependably unruly struggle characterized by appeals to administrative convenience, by deference to the claims of competing special imterest groups, by subjection to the ineluctable forces of institutional checks and balances, and ultimately by the tendency to accommodate political realities. ${ }^{17}$ Present first amendment doctrime permits the publication or dissemination of nearly all the

117. Consider, for example, the "Declaration of Policy and Statement of Purpose," of the Government in the Sunshine Act:

It is hereby declared to be the policy of the Umited States that the public is entitled to the fullest practicable information regarding the decisionmaking processes of the Federal Government. It is the purpose of this Act to provide the public with such information while protecting the rights of individuals and the ability of the Government to carry out its responsibihities.

Pub. L. No. 94-409, \& 2, 90 Stat. 1241 (1976). A brief examination of the voluminous legislative history of the federal Freedom of Information and Government in the Sunshine Acts reveals the amount of travail, compromise, and accommodation which was necessary to fashion the legislation according to this purpose, given the competing goals and conflicting interests involved. Consider only a few of these goals: (1) open government; (2) cutting costs of government; (3) discouraging undue litigation; (4) protecting the natioual security; (5) protecting the Constitutional right of personal privacy; (6) pursuing the need for economic stability and security; and (7) ensuring law enforcement effectiveness and efficiency. See, e.g., Statement by Rep. McCloskey, H.R. REP. No. 94-880, 94th Cong., 2d Sess., Part I at 39 (1976) and statements by Reps. Hutchinson and McClory, id., Part Il at 41-42.

The very length and complexity of the legislation that energed from the process of compromise and accommodation, which attempts to strike a balance between sucli competing goals as are listed above, ought to provide further doubt as to the wisdom of establishing a constitutional right to know: a constitutional right to know would inevitably require the judiciary to engage in such complex policy formulation. Consider but one of the basic provisions of the Administrative Procedure Act, 5 U.S.C. $\$ \S 551-559,701-706,1305$ (1976), regarding disclosures required of agencies. $I d . \S 552$. Requirements for publication in the Federal Register of certain information regarding basic agency procedures are set forth along with sanctions for noncompliance. Id. § 552(a)(1). Procedures for agency disclosure of information requested by the public are outlined. Id. $\$ 552(a)(6)$. Details of federal court procedure concerning complamts to enjoin agency withholding of records and order production are set forth. Among other issues, these provisions allocate the burden of proof to the agency, specify de novo consideration of the record, expedition of court proceedings, allocation of costs in the proceedings, and provide the sanctions of contempt and admmistrative discipline for noncompliance with a court order. Id. § 552(a)(4). This section also provides seven exemptions from the rigors of the Act: (1) matters specifically and properly establishcd by Executive Order to be kept secret in the interest of national defense or foreign policy; (2) matters solely related to internal rules and practices of an agency; (3) inatters specifically exempted from disclosure under other statutes; (4) trade secrets; (5) certain imteragency or intraagency memorandums or letters; (6) personal and medical files where disclosure would result in clearly unwarranted invasion of personal privacy; and (7) certain investigatory records compiled for law enforcement purposes. Id. $\$ 552(\mathrm{~b})$. The description of the above provisions constitutes but a bare sketch of the detailed balance struck in this particular area of disclosure of information to the public-but the bare sketch is sufficient to throw the complexity of the policy issue into mescapably bold relief. 
information that is in fact acquired, even if its acquisition was without the government's consent and its release is contrary to the government's wishes. ${ }^{118}$ Under this regime of freedom, the kind and amount of imformation about government which the public actually receives will be the random sum of what political competition can produce plus that which members of the press and other persons obtam, by a variety of only fortuitously successful investigatory devices, and decide to publisli. ${ }^{119}$

That such an untidy result could be deemed acceptable does not necessarily imply indifference to the possibility that the information about government so generated may fall short of the "optimal amount" needed by a "well-informed" electorate. It implies, rather, a willingness to bow to the inevitable fact that there is no principled way to determine what the optimal amount of information is in any event, and a conviction that this unruly way of deciding the issue is imphicit in processes of representative democracy prescribed by the Constitution. Since the general question of how mucli relevant information the government ouglit to reveal to the public is not susceptible to resolution in terins of constitutional primciple, the Constitution seems to have left it-along witl many if not nost issues about whose proper resolution no conscientious citizen is indifferent-to be decided by political competition.

A systein that resolves questions of public access to government information by turning to the political marketplace, while at the same time leaving the press free to publisl whatever information it can obtain by one means or anotler, is consistent not only with the aspect of our constitutional sclieme that assigns power to decide all but questions of constitutional primciple to the democratic processes but also with the aspect that checks governmental power by dividing and diffusing it among various imstitutions. Professor Bickel made this point when he described first amendment doctrime as creating an "adversary game between the press and governinent"120 which is analogous to the constitutional system of separation and balance of powers among the institutions of government. This system ordains that "men's ambition [be] joined to the requirements of their office, so that they push those requirements to the limit, which in turn is set by the contrary require-

118. This at least seems to be a fair reading of the implications of present doctrine. See, e.g., Landmark Communications, Inc. v. Virginia, 435 U.S. 829 (1978); New York Times Co. v. United States, 403 U.S. 713 (1971).

119. Commentators on the right to know have often suggested that the random nature of the kind and amount of information produced by the political marketplace is a significant cause for concern. See, e.g., Henkin, supra note 78, at 278. Neglected Constitutional Right, Access to Official Information: A Neglected Constitutional Right, 27 IND. L.J. supra note 82, at 209, 213, 217.

120. A. Bickel, The Morality of Consent 80 (1975). 
ments of another office joined to the ambition of other men."121 The system is not one "whose justification is efficiency, logic or clarity. Its justification is that it accommodates power to freedom and vice versa." 122 First amendment doctrine, under which the press is constitutionally free to publish and the government constitutionally free to withhold inforination, can be viewed from a similar perspective:

The First Amendment offers us no formula describing the degree of freedom of information that is consistent with necessary privacy of government decisionmaking. Rather . . . it ordains an unruly contest between the press, whose office is freedom of information and whose ambition is joined to that office, and government, whose need is often the privacy of government decision-making and whose servants are ambitious to satisfy that need. ${ }^{123}$

There is, however, a subtle danger lurking in the analogy between first amendment doctrine and the constitutional separation and balance of power among the imstitutions of government. Professor Bickel's contest metaphor is useful as a way of reconciling what might otherwise appear to be the doctrinal inconsistency between the press' freedom to publish and the government's power to withhold. The analogy of first amendment doctrine to the workings of the separation of governmental powers illummates the fact that the Constitution permits the press to perforin vigorously an informing function and even encourages such performance by removing the costs that would be imposed on publication if government restraint or punishment were allowed. But the Constitution does not mandate that the press inform the public, and the first amendment doctrine-separation of powers analogy ought not to be taken as a literal suggestion that the Constitution establishes the press as a "fourth branch" of government. The Constitution may perhaps be said to guarantee and thus to "mstitutionalize" press freedom. It cannot be said to mstitutionalize the press itself, or in any fornal sense to confer on it any governmental-or "constitutional"-role.

Indeed, an affirmative vindication of the value of well-inforined political debate or of the press' information-providing role might well undermine press freedom. If the first amendnient is to vindicate deniocratic values, it must assure that the press remains insulated from all attempts by the government to control the content of its publications. ${ }^{124}$

121. Id. at 86 .

122. Id.

123. Id. at 87 .

124. The courts, as the branch of government most removed from political control, seem best suited to ensure the integrity of the political process whicls is necessary to support meaningful representative government. If any particular majority at any particular time could "change the rules of the political game" to its systematic advantage, so as to ensure or at least make more likely its retention of power, then the integrity of the political process would surely be undermined. In the context of the first amendment, the task of ensuring the integrity of the political process is 
Freedom to publish without governmental control would be lost if courts, which are of course part of government, were to assert power to act as editors. But the courts in independently enforcing a governmental duty to disclose information would imevitably become active participants-with, indeed, controlling voices-im decisions about what information to publish:

If the courts recognize the right to know . . they will begin to perform the function of gathering information. They will also act as cditors, since only courts can apply the qualification inherent in the right to know. Editing will require judginent about what infornation to release to the public and what to withhold. ${ }^{125}$

Moreover, to the extent that the Court came to view the press as the public's information-gathering agent and to evolve doctrime which would enable the press to fulfill that role via special rights of access to governmental information, experience demonstrates that demands for concomitant legal accountability in the fulfillment by the press of its constitutional role would ultimately prove irresistible. ${ }^{126}$ The notion that the press is constitutionally required to fulfill an information-gathering role is quite at odds with a constitutional principle that protects its freedoin to do so.

\section{CONCLUSION}

In summary, each of the arguments for a right to know is based upon an implicit premise about the democratic processes prescribed by the Constitution that calmot withstand analysis. Indeed, analysis of the constitutional structure of government yields a conclusion quite contrary to the implication of a constitutional right to know governmental information. The Constitution prescribes a representative democracy, not a direct one. The Constitution yields no normative standard by which the clami of access to governmental information can be evaluated. And the question of whether citizens' demands for information

performed by enunciating doctrine that keeps political debate free from the attempts of particular majorities to control its content to their own advantage. It is not, of course, by any means an easy task for courts to identify instances of constitutionally forbidden attempts to control the content (and hence to determine the outcome) of political debate. See, e.g., First Nat'l Bank v. Bcllotti, 435 U.S. 765 (1978). Nor, more generally, is there an analytically well-developed route under the first amendment or any other provision of the Constitution to determine either what is the constitutionally guaranteed irreducible minimum amount of integrity of the political process or when legislative majorities have violated it. This issue, lowever, is, in all its frightening complexity, beyond the scope of this Article.

125. Goodale, Legal Piffalls in the Right to Know, 1976 WASH. U.L.Q. 29, 32.

126. If the press is given special access to governmental information as the public's representative, then arguably the press owes a fiduciary duty to the public to present such mformation "fully" or "fairly," as currently is required of the electronic inedia after Red Lion Broadcasting Co. v. FCC, 395 U.S. 367 (1969). See, e.g., Van Alstyne, supra note 66; Comment, supra note 5, at 182. 
ought to be honored is not merely quite unsuitable for judicial resolution, but also seems plainly to have been committed to the branches of government entrusted with making and admmistering the laws. The analysis supports the conclusion that a judicially enforceable right to know would be inconsistent with the deinocratic processes envisioned by the Constitution and thus could not be justified by a first amendment principle whose office is to vindicate those processes. The corollary of this conclusion is that the first amendment does not in principle guarantee that a well-informed citizenry with the press as its constitutionally appointed information gathering agent are values of affirmative, independent constitutional significance.

Present first amendment doctrine is basically consistent with these conclusions and thus is justified by legitimate first annendment principles. In the prior restraint and subsequent punishment cases, the value of free political speech has been vindicated. In the prison access cases, no independent constitutional value has been attached to a well-informed public opinion. And to the extent they can be explained by the Court's failure to weigh the value of the flow of information to the public in the constitutional balance, the press privilege cases fit withm the principle's confines. 